\title{
The Effect of Administrative Classification of Public Budget Expenses on Improving Effectiveness and Efficiency of Administrative Control in Public Sector Departments in Jordan-Field Study
}

\author{
Hamdan Moh'D Al -Hiyasat ${ }^{1}$ \\ ${ }^{1}$ Accounting Dept, Faculty of Business and Finance, The World Islamic Sciences \& Education University, \\ Jordan \\ Correspondence: Hamdan Moh'D Al -Hiyasat, Accounting Dept, Faculty of Business and Finance, The World \\ Islamic Sciences \& Education University, Jordan. E-mail: hamdan.hyasat@yahoo.com
}

Received: August 18, 2014

doi:10.5539/ijbm.v9n12p159

\author{
Accepted: October 21, $2014 \quad$ Online Published: November 22, 2014 \\ URL: http://dx.doi.org/10.5539/ijbm.v9n12p159
}

\begin{abstract}
This study aims at considering the effect of administrative classification of public budget expenses on improving effectiveness and efficiency of administrative control in public sector departments in Jordan-field study.

To achieve the aims of the study, questionnaire is developed and conducted .The questionnaire is distributed by hand to all financial managers and managers of interior control, heads of administrative control departments who are (168) in the study Community.

The Community consists of all public sector departments in Jordan whose budgets are among public budget law no (1) for the year (2013). They are (56) departments. The number of questionnaires distributed to the members is (168), but only (151) are returned back. Questionnaires that are suitable for statistical analysis are (145) with a percentage of $(86.3 \%)$ of all distributed questionnaires. A group of statistical analysis methods are used represented in (descriptive Statistic Measures), (One Sample T-Test), and (Reliability Analysis Alpha).

The results of the study indicate that there is a positive effect of administrative classification of public budget expenses on improving effectiveness and efficiency of performance of administrative control in public sector departments in Jordan. In light of the results that the study came up with, a group of recommendations is put .The most important recommendation is that the necessity to enlarge the use of administrative classification of public budget expenses in departments of public sector in Jordan according to a plain approach due to its effect on increasing effectiveness and efficiency of administrative control of public expenses.
\end{abstract}

Keywords: administrative classification of expenses, public budget, efficiency, adequacy administrative control, public sector

\section{Introduction}

Budget predations and accounts are considered among the most important means of public work administration in different levels. It is also the main base to systematic cycle from four stages starting from planning then budget accounts and ends with following up and evaluation, then it goes back again to planning and so on.

As the role that the government has in economic and social areas increases especially in achieving development and economical stability and social luxury, the importance of evaluating the effects of governments acts increases in order to take decisions on correct bases. Here arises the importance of methods used in budget classification that must cope up with accounts and needs, reality and nature of each state. Accounts system should also provide data that is sufficient for budget needs. Tables and data and accounts that are included in public budget should be classified and ranked in a way enables public authorities to take decisions that achieve desired goals (Al-Mahaini, 2009, p. 65).

In this respect, the state public budget project represents the government vision for the next stage that relies on greatly depending on national incomes to cover expenses side by side with raising the level of public spending, improving its productivity level that assures improving government services to citizens. In addition to that, governments can intense efforts towards deepening the dependency of governmental units on their self incomes in financing their expenses, and decreasing their dependency on public treasury support. Because of the increase 
of the economic role and ramification especially in the third world economics, this results in increasing the amount of public expense both in current and capitalist forms, and imposing more taxes to face the increase in public expense amount. This increases citizens' burden and so other methods should be searched that achieve the most possible amount of productivity adequacy and pre-specified goals.

This study, therefore, measures the effect of administrative classification of public budget expenses on improving effectiveness and efficiency of administrative control performance in public sector departments in Jordan.

\subsection{Problem of the Study}

The most important issues that face public money administration as mentioned in (public budget law for the year, 2013, p. 181) is in continuing in growing in the budget expenses, (Mahmoud, 2011, p. 89) the bad administrative system and non coping with fast development in practical and economical life results in increase in government real expense. This leads to increasing the burden of citizens public expenses (Mubarek, 2013, p. 37) mentioned that government public budget of state is considered the basic origin for government accounting system. Moreover, it is considered as the base that real implementation results are compared to. So, the map of accounts and its classification in accounting public system should keep up with budget system applied in the state. The framework of public accounts is a reflection of budget framework. Consequently, it is possible to state the problem of the study to answer two questions as the following:

1-What is the effect of public budget expenses administrative classification on improving the efficiency of administrative control performance in public departments in Jordan?

2-What is the effect of public budget expenses administrative classification on improving the adequacy of administrative control performance in public departments in Jordan?

\subsection{The Importance of the Study}

The study importance comes from the fact that it tries to explore the effect of administrative classification of public budget expenses on improving the effectiveness and efficiency of administrative control in departments of public sector in Jordan. Also the study shows the importance of this classification and its reflections on administrative control aims representing in achieving the most possible productivity efficiency and ensuring application of administrative policies as they prescribed in advance.

The study also gets importance through scientific addition that the results come up with. In addition, to assumed recommendations to improve effectiveness and efficiency of control methods and tools used in public sector departments in Jordan.

\subsection{The Objectives of the Study}

This study attempts to achieve the following objectives:

Firstly, to recognize the administrative classification of public budget expenses and showing its effect on improving efficiency of administrative control in departments of public sector in Jordan.

Secondly, exploring the effect of administrative classification of public budget expenses in improving administrative control performance in public sector departments in Jordan.

\section{Concepts of the Study}

The most important concepts of the study are the following:

Administrative Classification: means distributing public budget incomes to government administrative units according to the state system framework to cover the actions that every government administrative unit do according to its abilities and in limits of incomes (Abed el Jaleel, 2013, p. 48).

Administrative Control: can be defined as the action that administration make in the organization to ensure that the work is going on according to policies and plans set to achieve the organization aims, also to show the deviations and work to repair them (Al-Qdah, 2008, p. 115).

Public Budget: The second part of public budget organization law no (58) year 2008 defines public budget as government plan for a next financial year to achieve national desired aims within a medium financial range.

Effectiveness: concept indicates that how success in achieving aims. Evaluating effectiveness demands setting goals that are desired to be achieved through prescribed goals that are prescribed in advance (Al-Hiyasat \& Al Shorafa, 2012, p. 128).

Efficiency: means efficiency in applying desired job that lead to achievement of specified results in least expense and time and effort (Al-Rahahleh, 2010, p. 18). 
Public Sector is defined by the second section of public sector developing system and observing governmental performance no (2) year 2005 as ministries, governmental departments and public organizations.

\subsection{Theoretical Side}

\subsubsection{The Concept of Administrative Classification of Public Budget Expenses}

The second part of financial system and its modifications no (3) year 1994 defines public expenses "all amounts devoted to face imposed commitments according to legislations on work". Administrative classification could be considered as distributing public expenses according to administrative units of state that do spend them. In other words, classifying public expenses in budget is according to system administrative units in government system and its administrative correlations. So, the administrative classifications used rank public expenses only. It also reflects system framework of government administrative units, and is ever dispensable as these units reflect public expense authority (Al-Khatib \& Almahaini, 2008, p. 319), (Al-Hijawi, 2004, p. 176).

Al-Hilali states that administrative classification helps to recognize the gross expenses and deputies assigned to each separate department. This could enable comparing real expenses of each department during many time periods easily (Al-Fasfous, 2010, p. 59) discussed state public expenses administrative classification characteristics that can be classified in the following points:

- It helps in anticipating necessary data of expenses of each unit of administrative units.

- It can be considered as a tool to state responsibility range of every administrative unit, applying inquiry principle about any deviation in fulfilling prescribed program that contributed to set its assumption.

- This classification can observe and follow up changes that happen to administrative unit activity from year to year.

- It clarifies the amounts that represent annual roof permitted to expense.

Abd el Jaleel and Al-Bdour see that administrative classification has a great importance in distributing treasury incomes among administrative units and limits responsibilities of each unit. It also controls collection tasks of each unit and its expense.

In respect of state public budget, expenses classification, as stated by (Al- Wedian \& Al Hadab, 2010, pp. 70-71) aims at achieving many goals:

- Supplying necessary data to prepare estimations of budget and facilitating its application.

- Achieving full correlation between estimated uses of every unit and programs assigned to be fulfilled.

- Applying efficient control on public expenses. This can be through comparing real expenses with expenses assigned to it, and comparing real expense with expenses assigned to each kind of uses.

- Analyzing economical and social effects of budget.

Consequently, the researcher agrees with previous points of views about the importance of administrative classification to public budget expenses in that it distributes treasury incomes among administrative units and prescribes each unit's responsibilities due to expenses. This leads to applying inquiry principle for any deviation. Finally, it helps analyzing expenses and determining their directions. It also enables comparing public expenses for different years, maintaining the same level of public services introduced, decreasing public treasury waste, and also raising the productivity adequacy of expenses up to system laws.

\subsubsection{The Concept of Administrative Control}

Administrative control is one of the important administrative duties as it aims at ensuring performance quality, making sure of fulfilling determined aims as they are planned. Many writers and researchers introduce different definitions of administrative control. Most of them have one aspect and aim represented in keeping organization incomes and ensuring good fulfilment of tasks, achieving aims in the best ways, decreasing deviations (Al-Harbi, 2003, p. 16) defines administrative control as measuring task and correcting it in order to ensure that aims have been achieved, and the plans are applied in the right way. Whereas (Al-Hijazi, 2010, p. 85) defines it as the organizational plan that includes methods and procedures specialized mainly in fulfilling policies and administrative procedures and achieving adequacy of planned operations.

\subsection{Administrative Control Aims}

Administrative control is considered a kind of inner control that aims at:

- Achieving the most possible productivity adequacy, ensuring fulfilling administrative policies according to the plan that has been assigned (Al-Hijawi, 2004, p. 242) and (Al-Matarneh, 2006, p. 214). 
- Administrative control includes organizational plan, accordition means, procedures aimed at achieving the most possible amount of productivity, along with encouraging commitment of policies and administrative decisions (Al- Khrisat, 1998, p. 36).

- Administrative control aims at achieving productivity adequacy and encouraging administrative policies commitment. Among the procedures that administration set to achieve administrative control is the planed budgets, standard expenses, graphs, maps, transaction and turnover studying, periodical reports, training programs for employees. (Al-Dhnibat, 2012, p. 176).

- Administrative control permits distributing jobs and responsibilities to achieve sufficient amount of ability in different ways such as performance reports and planning budgets (Al-Rimahi, 2009, p. 108).

Marginson indicates that there is a positive effect of administrative control on all organization tasks especially administrative and financial and systems in force (Al-Tarawneh \& Allouzi, 1995, p. 146) point that administrative control helps discover any deviation in plan in early stages of application, and contributes to minimize expense increase, slackness phases and administrative corruption.

Researcher agrees with what is motioned of views about the aims of administrative control as an important tool to increase productivity adequacy, encourages workers to comply with prescribed policies of public sector departments administration.

\subsection{What Distinguishes the Study?}

What distinguishes the study is that it tackles one of the most important tools of financial policies in public sector departments in Jordan represented in administrative classification to public budget expenses and stating its effect on improving effectiveness and efficiency of administrative control. The researcher hopes to introduce scientific material that could be useful in work control area depending on the results of the answers of the study sample for the questionnaire items introduced to them.

\section{The Model of the Study}

Table 1 shows the model of the study which explains the independent variable expected to have an effect on dependent variables in improving effectiveness (efficiency) and adequacy of the role of performance of administrative control in Jordan. Figure 1 indicates that:

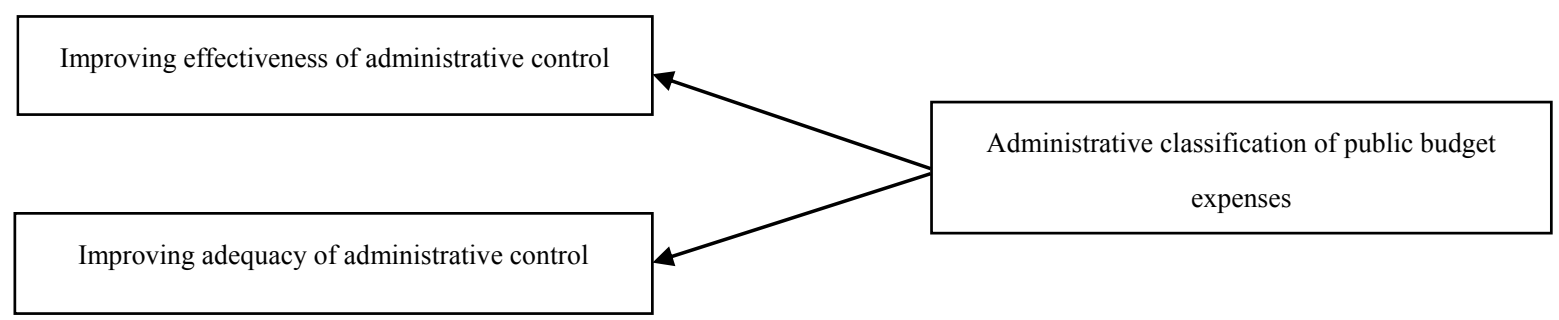

Figure 1. The relationship between administrative control and administrative classification of public budget expenses

\subsection{Hypotheses}

To achieve study goals, hypotheses have been structured in their nil form as follows:

H01: There is no effect of administrative classification of public budget expenses on improving efficiency of administrative control in public sector departments in Jordan.

H02: There is no effect of administrative classification of public budget expenses on improving adequacy of administrative control in public sector departments in Jordan.

\subsection{The Study Approach}

The researcher uses descriptive analytical approach through presenting the results of the study sample for the questionnaire items. Data has been analyzed using suitable statistical methods after testing reliability of hypotheses for statistical analysis.

\subsection{Data Collection Resources}

The researcher depends on two resources to collect data; initial resources through field study represented in 
developing a questionnaire that gets its original data from what is filled in by people who answered the questionnaire. And secondary resource through legislations (laws, systems) issued by government in Jordan, in addition to references and scientific journals, reports that specialists go through in this area in order to specify theoretical framework of this study.

\section{The Study Instrument}

To achieve the study aims, necessary data is collected by the questionnaire which is developed after reviewing theoretical framework, items are developed depending on the questionnaire used the study of (ALQdah, 2008). Then the main issues have been defined that will be tested by the questionnaire. It is introduced to (7) members of teaching committee in National Islamic University, in addition to (4) financial consultants in government departments in Jordan, in order to test the questionnaire external reliability. Their notes have been taken into consideration, and so necessary modifications have been made in light of these notes. Also, the questionnaire includes two main parts. The first part is devoted to data collection related to persons who answered the items of the questionnaire, (academic qualification, years of experience) that have been measured through years (1-2) from the questionnaire.

The second part includes questions measuring the two hypotheses of the study that are (15) questions in order to study the effect of administrative classification of public budget expenses on improving the effectiveness and efficiency of the performance of administrative control in public sector departments in Jordan.

And to test the study hypotheses, items (3-11) are devoted to measure the first hypothesis. Items (12-17) are assigned to measure the second hypothesis.

In consideration of the whole stability coefficient of the study, internal consistency coefficient for variables is used according to (Cronbach Alpha) where it is evident that consistency coefficient of the study variables as a whole equals $(77.8 \%)$ which is an acceptable percentage for the study purposes and to rely on its findings (Sekaran, 2010). In order to use data collected to serve the study purposes, reliability and objectivity of the questionnaire have been tested. It is developed depending on dividing each hypothesis of the study into analytical units that cope up with Likert scale (Five Point Likert Scale). Table 1 explains this.

Table 1. Likert five point scale

\begin{tabular}{llllll}
\hline Effect degree & Does not affect & Weak & Medium & High & Very high \\
\hline Ratio weight & 1 & 2 & 3 & 4 & 5 \\
\hline
\end{tabular}

According to this table, the decision rule is: effect is acceptable when the median score of the study sample members' answers on the questionnaire equals (3) and more.

\subsection{Community and Sample of the Study}

The study Community consists of all public sector departments in Jordan that their budgets included in public budget law of the state no (1) for the year (2013). These are (56) departments up to the date of conducting this study. The study sample consists of all financial administrators, administrators of interior control, and heads of administrative control in the study Community who are (168).Questionnaires (168) are distributed to members of the study, and the returned back questionnaires are (151) only. The questionnaires that are suitable for statistical analysis are (146) with a ratio of (86.3\%) of all distributed questionnaires.

\subsection{Characteristics of the Study Sample}

Descriptive statistic is used to analyze the study sample distribution according to personal characteristics and demography. Results are the following: 
Table 2. The distribution of the study sample according to the characteristics of the study sample

\begin{tabular}{lllllll}
\hline Study group & $\begin{array}{l}\text { Below } \\
\text { bachelor }\end{array}$ & Bachelor & $\begin{array}{l}\text { High } \\
\text { diploma }\end{array}$ & Master & Doctorate & Frequency \\
\hline Financial administrators & 0 & 17 & 2 & 9 & 4 & 42 \\
Interior control administrators & 0 & 31 & 4 & 5 & 6 & 46 \\
Heads of interior control & 0 & 48 & 1 & 6 & 2 & 57 \\
sections & 0 & & & & 12 & 145 \\
Total & $0.0 \%$ & $73.1 \%$ & $4.8 \%$ & $13.8 \%$ & $8.3 \%$ & $100 \%$ \\
Ratio & & & & & & \\
\hline
\end{tabular}

From the Table 2, we can notice that most members of the study sample are bachelor degree graduates $(73.1 \%)$, then master degree $(13.8 \%)$ and then the doctorates where their ratio is up to $(8.3 \%)$. The high diploma holders are up to the ratio of $(4.8 \%)$, and those who are below bachelor degree is in the ratio of $(0.0)$. This is an indicator that questionnaires are responded to by a sample most of which are scientifically qualified. Moreover, they have knowledge about public budget expenses administrative control and its effects. They are also able to understand questionnaire items and answer them efficiently.

Table 3. The distribution of the study sample according to years of experience

\begin{tabular}{llllll}
\hline Study group & $1-5$ years & $6-10$ years & $11-15$ years & 16 and more years & frequency \\
\hline $\begin{array}{l}\text { Financial administrators } \\
\text { Interior }\end{array} \quad$ control & 0 & 5 & 9 & 28 & 42 \\
$\begin{array}{l}\text { administrators } \\
\text { Heads of interior control }\end{array}$ & 9 & 2 & 14 & 30 & 46 \\
sections & 9 & 16 & 13 & 19 & 57 \\
Total & $6.2 \%$ & 23 & 36 & 77 & 145 \\
Ratio & & $15.9 \%$ & $24.8 \%$ & $53.1 \%$ & $100 \%$ \\
\hline
\end{tabular}

We can notice from table 3 that years of experience of the sample of the study members is concentrated in the ratio percentage of (16) years and more as their ratio is up to (53.1\%). This is considered an indicator of high degree of the level of practical experience of the subjects in the study. The ratio of workers in the range (1-5) years does not exceed (6.2\%) whereas (11-15) years range has reached up to $(14.8 \%)$, but (6-10 years range is at the ratio of $(15.9 \%)$.

\subsection{Data Analysis Methods}

The researcher collected data for field study by subject's answers to questionnaire items. These data are input into computer, processed by statistical program, Statistical Package For Social Science, (SPSS) using the following statistical methods:

1)-(Descriptive Statistic Measures) to describe the characteristics of the study sample such as; medians, frequencies, ratios and standard deviation.

2)- (One Sample T-Test) to prove or negate study hypotheses.

3)-(Reliability analysis Alpha) to measure stability of the study instrument and its reliability degree.

\subsection{Test Hypotheses}

\subsubsection{The Results of Testing the First Hypothesis}

There is no effect of administrative classification of public budget expenses on improving efficiency of administrative control in departments of public sector in Jordan.

To test this hypothesis, median and standard deviation have been calculated to describe answers of the study sample members. Table 4 shows this. 
Table 4. The effect of administrative classification of public budget expenses on improving efficiency of administrative control in departments of public sector in Jordan

\begin{tabular}{|c|c|c|c|}
\hline $\begin{array}{l}\text { Serial } \\
\text { number }\end{array}$ & Item content & $\begin{array}{l}\text { Arithmetic } \\
\text { median }\end{array}$ & $\begin{array}{l}\text { Standard } \\
\text { deviation }\end{array}$ \\
\hline 3 & $\begin{array}{l}\text { Administrative classification contributes to increasing administrative control efficiency } \\
\text { on public expense }\end{array}$ & 4.187 & 0.791 \\
\hline 4 & $\begin{array}{l}\text { Administrative classification contributes to determining standard use of permitted } \\
\text { allowances. }\end{array}$ & 4.102 & 0.673 \\
\hline 5 & Administrative classification contributes to preserve introduced allotted services. & 3.661 & 0.856 \\
\hline 6 & $\begin{array}{l}\text { Administrative classification helps in the operation of comparing between public } \\
\text { expenses for different years. }\end{array}$ & 3.114 & 0.752 \\
\hline 7 & $\begin{array}{l}\text { Administrative classification contributes to prevent repeating or making mistakes or } \\
\text { deviations in public expenses. }\end{array}$ & 3.365 & 0.541 \\
\hline 8 & $\begin{array}{l}\text { Administrative classification contributes to make employees recognize the importance } \\
\text { of information in decision making. }\end{array}$ & 3.461 & 0.765 \\
\hline 9 & $\begin{array}{l}\text { Administrative classification contributes to analyzing public expenses and determining } \\
\text { their directions which helps in inquiry among pre prescribed goals. }\end{array}$ & 4.258 & 0.733 \\
\hline 10 & $\begin{array}{l}\text { Administrative classification contributes to raising productivity efficiency of expense } \\
\text { according to goals to be achieved. }\end{array}$ & 3.370 & 0.928 \\
\hline 11 & $\begin{array}{l}\text { Administrative classification contributes to control expense according to legislations in } \\
\text { force. }\end{array}$ & 3.836 & 0.813 \\
\hline $3-11$ & All items together & 3.706 & 0.892 \\
\hline
\end{tabular}

Table 4 above indicates that the arithmetic median of the study sample members answers for administrative classification and its effect on improving efficiency of administrative control performance in public sector departments in Jordan is positive towards all items (3-11).This is because their arithmetic median is higher than the arithmetic median of measurement instrument which is up to (3).

It is noticed that the ninth item is the most agreed upon which states that Administrative classification contributes to analyzing public expenses and determining their directions which helps in inquiry among pre prescribed goals. And the sixth item is the most items that is least agreed upon. This item says that Administrative classification helps in the operation of comparing between public expenses for different years.

The whole arithmetic median of answers of the study sample on all items reaches (3.706) and the standard deviation is $(0.892)$ which is a standard deviation that is statistically indicative in a positive form.

The arithmetic median of items of the first hypothesis consists of is compared to the standard point (3) is the hypothesis acceptance standard using T-Test as shown in the table number (5).

Table 5. First hypothesis test results

\begin{tabular}{lllllll}
\hline Number & $\begin{array}{l}\text { Arithmetic } \\
\text { median }\end{array}$ & $\begin{array}{l}\text { Standard } \\
\text { deviation }\end{array}$ & Calculated T & Freedom degrees & P-Value & Hypothesis result \\
\hline 145 & 3.706 & 0.892 & 5.787 & 144 & 0.000 & refused \\
\hline
\end{tabular}

First hypothesis test results indicate that calculated $\mathrm{T}$ value reaches to (5.787) and the value of $\mathrm{P}$ value is $(0.000)$ which is below indication level $(0.05>a)$ and so it is statistically indicative. So, the nil hypothesis is refused and the substitute hypothesis is accepted. This provides that there is an effect of administrative classification of public budget expenses on improving the efficiency of administrative control performance in public sector departments in Jordan.

The results of this study agree with what (AL-Hilali, 2002) points that administrative control enables comparing real expenses of each unit during periodical whiles easily. Results also agree with what (Al-Fasfous, 2010) suggests that administrative control leads to application of inquiry principle about any failure in fulfilling the programs, and between what is planned to. Also the results of this study cope up with what (Al-Wedian, \& AlHadab, 2010) state that administrative control leads to imposing efficient control on public expenses. 


\subsubsection{The Results of Testing the Second Hypothesis}

H02: There is no effect of administrative classification of public budget expenses on improving efficiency of performance of administrative control in public sector departments in Jordan.

To test this hypothesis, arithmetic median has been calculated and also the standard deviation to describe the sample members answers. Table 6 shows this.

Table 6. The effect of administrative classification of public budget expenses on improving efficiency of performance of administrative control in public sector departments in Jordan

\begin{tabular}{|c|c|c|c|}
\hline Serial no & Item content & $\begin{array}{l}\text { Arithmetic } \\
\text { median }\end{array}$ & $\begin{array}{l}\text { Standard } \\
\text { deviation }\end{array}$ \\
\hline 12 & $\begin{array}{l}\text { Administrative classification contributes to increasing efficiency of administrative } \\
\text { control on public expense. }\end{array}$ & 3.961 & 0.922 \\
\hline 13 & $\begin{array}{l}\text { Administrative classification contributes to achieving works at specified time and } \\
\text { effectively. }\end{array}$ & 3.233 & 1.260 \\
\hline 14 & $\begin{array}{l}\text { Administrative classification contributes to diagnose problems related to expense and } \\
\text { find solutions to them. }\end{array}$ & 3.290 & 0.879 \\
\hline 15 & $\begin{array}{l}\text { Administrative classification contributes to explain workers duties and their } \\
\text { responsibilities related to expense. }\end{array}$ & 3.174 & 1.032 \\
\hline 16 & $\begin{array}{l}\text { Administrative classification contributes to organize administrative operations and } \\
\text { work procedures. }\end{array}$ & 3.388 & 0.435 \\
\hline 17 & Administrative classification contributes to limit public treasury waste. & 3.456 & 0.673 \\
\hline $12-17$ & All items together & 3.417 & 0.711 \\
\hline
\end{tabular}

Table 6 indicates that arithmetic median of the study sample members for administrative classification and its effect on improving the performance administrative control efficiency in public sector departments in Jordan is positive to all items (12-17) because their arithmetic medians are higher than arithmetic median of the measurement instrument which is (3). It is noticed that item (12) is the most agreed upon. This item tastes that Administrative classification contributes to increasing efficiency of administrative control on public expense. And the fifteenth item is the most one that is least agreed upon. It states that Administrative classification contributes to explain workers duties and their responsibilities related to expense. Moreover, the whole arithmetic median of the study sample members' responses on all items is (3.417) and the standard deviation is $(0.711)$ and it is an arithmetic median that is statistically indicative in a positive form. The arithmetic median of items that form the second hypothesis is compared with the standard point (3) hypothesis acceptance standard using (One Sample T-Test) as shown in the following table.

Table 7. Second hypothesis test results

\begin{tabular}{lllllll}
\hline No & $\begin{array}{l}\text { Arithmetic } \\
\text { median }\end{array}$ & $\begin{array}{l}\text { Standard } \\
\text { deviation }\end{array}$ & Calculated T & Freedom degrees & P-value & Hypothesis result \\
\hline 145 & 3.417 & 0.711 & 4.926 & 144 & 0.000 & refused \\
\hline
\end{tabular}

The second hypothesis test results, in the above table, show that $\mathrm{T}$ value calculated is (4.926) and the $\mathrm{P}$ value is $(0.000)$ which is below indication level $(0.05>\mathrm{a})$ and so it is statistically indicative. So that, the nil hypothesis is refused and the substitute hypothesis is accepted. This hypothesis states that there is no effect of administrative classification of public budget expenses on improving adequacy of administrative control in public sector departments in Jordan.

Results of the current study agree with what (Al- Tarawneh \& Al-louzi, 1995) came up with that administrative control leads to discover any deviation in the plan in early stages of application, and, limits the increase of expenses and forms of administrative slackness and corruption. This study results also agree with what (Abd el Jaleel \& Al- Bdour, 2006) imply that administrative classification contributes to budget incomes distribution to 
administrative units and determine responsibilities of each unit and control its expenses.

\section{Results and Recommendations of the Study}

\subsection{Results}

After conducting suitable statistical analysis to the study data, the following results have been found:

1)-Study results indicate that there is a statistically indicative effect of administrative classification of public budget expenses on improving the efficiency of performance of administrative control in public sector departments in Jordan. The whole arithmetic median of the sample responses on all items has reached up to (3.706) and the standard deviation is (0.892).

2)-Study results indicate that there is a statistically indicative effect of administrative classification of public budget expenses on improving the adequacy of performance of administrative control in public sector departments in Jordan. The whole arithmetic median is (3.417) and the standard deviation is (0.711)

\subsection{Recommendations}

In light of the study results, it recommends the following:

- The necessity to enlarge the use of administrative classification of public budget expenses in public sector departments in Jordan according to a plain and specific approach because of its effect on increasing efficiency of administrative control in public expense.

- It should be concentrated on increasing dependency on administrative classification public budget expenses in public sector departments in Jordan due to its effect on increasing adequacy of administrative control on public expense.

Conducting more studies on the ways to improve effectiveness and efficiency of administrative control performance in public sector departments in Jordan in order to be effective control headed towards achieving stated financial and economical aims.

\section{References}

Abd-el-Jaleel, T., \& Hassan, A. M. (2013). Governmental Accounting (3rd ed.). Jordan University, Amman Jordan.

Al Gdah, H. S. S. (2008). Administrative Control and its relation to performance Adequacy, Applied Study on workers in Jordanian Ministry of Health. Arabic Journal of Administrative Development, 28(2), 111-143.

Al-ahijazi, W. H. (2010). Interior editing bases, Applied Practical Entry (1st ed.). University Education House, Alexandria.

Al-Dhnibat. (2012). Editing Accounts in light of universal standards: Theory and Application (4th ed.). Amman, Jordan.

Al-Fasfous, F. (2010). Governmental Accounting (1st ed.). Dar Konouz al Maarifa al Elmieh for publishing and distribution, Amman, Jordan.

Al-Harbi, A. B. (2003). Administrative Control and its relation to performance Adequacy-Applied Study on Customs superintendents in King Khalid Airport Customs. Master Thesis unpublished, University of Nayef Arab police Science, Riyad, Sauadi Arabia.

Al-Hijawi, H. A. A. (2004). The Scientific and Practical bases in governmental Accounting (2nd ed.). Dar Hamed for publishing and Distribution, Amman, Jordan.

Al-Hiyasat, H., \& Al-Shorafa, A. (2012). The Role of the Electronic Receipt of Public Revenues in Enhancing the Effectiveness of Control in the Public Sector in Jordan. Mu' tah Lil-Buhuth Wad-Dirasat, Mu'tah University.

Al-khateeb, K. S., \& Mahaini, M. K. (2008). Governmental Accounting (1st ed.). Dar Wael for Publishing and distribution, Amman, Jordan.

Al-Khrisat, H. F. (1998). Editing in Companies (1st ed.). Dar Afaq for Publishing and Distribution, Amman Jordan.

Al-Mahaini, M. K. (2009). Governmental Accounting. Brochures of Arab Organization of Administrative Development, Egypt.

Al-Matarneh, Q. F. (2006). Contemporary Accounts Editing, Theoretical View (1st ed.). Dar el Maseereh for publishing and distribution and printing, Amman Jordan. 
Al-Rahahleh, M. Y. (2010). Assessing Administrative Performance of Jordanian Accounting Bureau. Al Manareh for Research and Studies, Al el Bait University.

Al-Rimahi, N. M. A. (2009). Governmental Accounting (1st ed.). Dar Safaa for Publishing and Distribution, Amman, Jordan.

Al-Tarawneh, T. A., \& Allouzi, S. A. (1995). Administrative Control Reality as seen by Workers in Governmental Departments in Al Tafeeleh governorate. Muta for Research and Studies, 10(6), 145-180.

Al-Wedian, L., \& Al Hadab, Z. (2010). Governmental Accounting (1st ed.). Dar el Bedayeh, publishers and distributers, Amman, Jordan.

MAhmoud, R. S. (2011). Governmental Accounting (1st ed.). Dar el Maseereh for publishing and Distribution and Printing, Amman, Jordan.

Marginson, D. (2002). Management Control Systems \&Their Effects on Strategy Formation at Middle Management Level: Evidence from AU.K. Organaization Strategic Management Journal, 23, 1014-1037.

Mubarek, S. (2013). National and Governmental Accounting (1st ed.). Al Wafaa Law Library, Alexandria, Egypt.

Sekaran, U. (2010). Research Methods for Business: A skill Building Approach (5th ed.). John Wiley \& Sons, Inc.

The Hashemite kingdom of Jordan. (1994). The Financial System. Official Newspaper.

The Hashemite kingdom of Jordan. (2005). System of public Sector Development and governmental Performance Observing.

The Hashemite kingdom of Jordan. (2008). Public Budget Organization Law.

The Hashemite kingdom of Jordan. (2013). Public Budget Organization Law.

\section{Copyrights}

Copyright for this article is retained by the author(s), with first publication rights granted to the journal.

This is an open-access article distributed under the terms and conditions of the Creative Commons Attribution license (http://creativecommons.org/licenses/by/3.0/). 